5

\title{
Watershed Assessment using an Integrated Modeling Approach
}

Wael M. Khairy, Alim P. Hannoura, and Alex McCorquodale

The emergence of information technologies and watershed management approaches enable decision-makers to establish predictive relationships between different land-use activities and the corresponding sediment and nutrient loads discharged from the watershed. Furthermore, these approaches are extended to assess the impacts of watershed waste loads on the receiving aquatic systems. For example, modeling of water quality provides the means to assess the effectiveness of nutrient reduction programs on the eutrophication process in the receiving water body. This is a complex process to manage because it requires tying the environmental outcomes of a management policy to land-use and socioeconomic implications.

This chapter presents a research study of the impacts of land-use activity on sediment and nutrient loads. A case study on the simulation of Tangipahoa Watershed and Lake Pontchartrain Ecosystems is emphasized. Surface runoff from the watersheds represents a major component in the water balance of Lake Pontchartrain. Estimates of waste loads entering the lake have to be made using a water quality model accounting for land-use and agricultural processes. This requires the use of a continuous time model to simulate watershed hydrology, surface and subsurface water quality, and impacts of crop management. The Soil and Water Assessment Tool, SWAT, and the Geographical Resources Analysis Support System, GRASS, were used in the case study. The United States Geological Survey (USGS) stream flow records and the Louisiana Department for Environmental Quality (LADEQ) water quality data set were used for the calibration and verification of the model.

\footnotetext{
Khairy, W., A. Hannoura and J. McCorquodale. 2001. "Watershed Assessment using an Integrated Modeling Approach." Journal of Water Management Modeling R207-05. doi:

10.14796/JWMM.R207-05.

(C) CHI 2001 www.chijournal.org ISSN: 2292-6062 (Formerly in Models and applications to Urban Water Systems. ISBN: 0-9683681-4-X)
} 
The baseflow component of the surface stream was quantified using the modified recursive digital filter technique. The curve-number and the available moisture capacity proved to be the most important calibration parameters in the hydrologic component calibration, while the soil erosion factor and the rain water quality were important in the sediment and water quality components. The accounting of spatial variability of watershed parameters is one of the major strengths of the SWAT-GIS model. Using the integrated approach involving SWAT, GRASS, and a relational database containing temporal weather information, the hydrology, soil, and crop management conditions renders study of large watershed surface and sub-surface processes possible.

\subsection{Introduction}

Geographic information systems (GIS) are being increasingly used to enhance the development of spatially-distributed input data and to visualizing the model results of comprehensive simulation models (Srinivasan and Engel, 1991, Rewerts and Engel, 1991). This chapter presents an application of GRASS, (U.S. Army, 1988), with a distributed-parameter, continuous-time nonpointsource-pollution model, SWAT. This tool (SWAT 99.1, GRASS, and SWATGRASS interface) was developed by the Blackland Research Center, at the Texas Agriculture Experimental Station in Temple, Texas and was released in 1999. This integration proved to be effective and efficient for the development and management of input data, and visualization of the output results. The interdependence of sediment and nutrient loads under different watershed landuses has been studied. The releases of chemicals can cause various impacts possibly affecting human health or contributing to the ecological degradation of the water bodies.

\subsection{The SWAT-GIS Tool}

SWAT is capable of continuous time simulation and flexible domain delineation (Williams, et al., 1985). The development and management of input data for such a model are often difficult, due to the level of aggregation and the nature of spatial distribution. SWAT can be supported by GRASS, and Arcview (Srinivasan and Engel, 1991a, and 1991b). The integration of SWAT with a GIS tool, including a relational database management system, extends its ability to readily extract input data required for modeling large watersheds (Srinivasan and Engel, 1991a). The SWAT input interface automatically delineates a 
watershed, extracts the input data from geographical map layers and creates the associated relational databases for each subbasin (Arnold et al., 1993). Soils, land-use, weather, management, topographic, and groundwater data are developed and written to appropriate model input files (Neitsch et al., 1999).

\subsection{Development of SWAT-GRASS Input Interface}

The SWAT-GRASS input interface was developed on principles similar to those detailed in Rewerts and Engel, (1991), where the ANSWERS model (a watershed planning model) was integrated with GRASS. Figure 5.1 shows the structure of the user's view of the input interface and its interaction within SWAT.

The SWAT-GRASS input interface has a project manager and an engine for controlling, extracting, and aggregating the data, and for viewing, editing, and checking SWAT input data files. The function of the project manager is to interact with the user to prepare data for the SWAT input files. Most SWAT input data are derived from GIS raster map layers. The project manager executes a series of steps to prepare the inputs for SWAT. Multiple, concurrent simulation projects are facilitated, each being identified by a project name. The four basic layers needed to extract inputs for the SWAT model include a basin layer, an elevation layer, a soils layer, and a land-use layer.

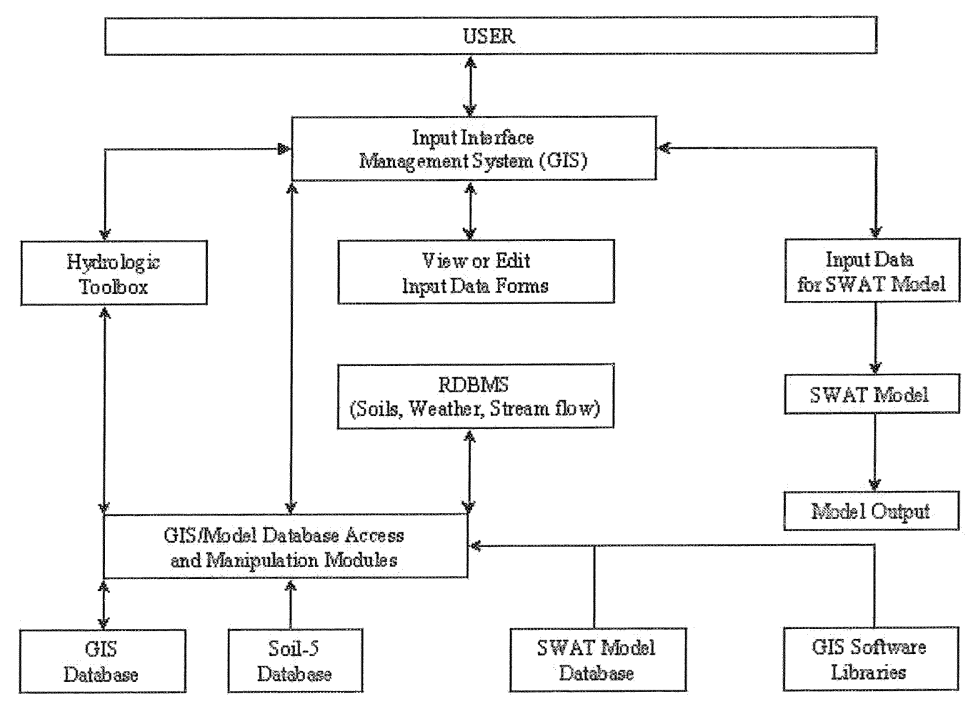

Figure 5.1 User's view of SWAT-GRASS input interface. 
SWAT delineates the basin into subbasins based on soil type, land-use, and topography. This requires tools to aggregate inputs at both basin and subbasin levels for the model. The method of aggregation varies and depends on the type of input. The general methods to aggregate data in the SWAT-GRASS input interface are: mean, mode (dominant), weighted average, discrete or segment average, and geometric mean.

The model computes the impact of land-use and management changes on water, sediment and agricultural chemical yields in large ungaged watersheds. The major components of the hydrologic balance and their interactions are simulated in the SWAT model including surface runoff, lateral flow in soil profile, groundwater flow, evapotranspiration, channel routing, pond and reservoir storage. In-stream pesticide, nutrient transport and transformation routines, bacteria growth, and wetland simulation have been added to the model recently (Arnold et al., 1999).

\subsection{Case Study}

In this chapter, the integrated SWAT-GRASS tool was applied to Tangipahoa River Watershed, a component of the Lake Pontchartrain ecosystem in Louisiana, USA. The study area is about 518,000 acres $(210,000 \mathrm{ha})$ as shown in Figure 5.2. The major land-uses in Tangipahoa watershed are presented in Table 5.1.

Table 5.1 Land-uses in the Tangipahoa watershed.

\begin{tabular}{ccc}
\hline Land-use & Area (acres) & Percentage (\%) \\
\hline Crop Land & 25,880 & 5 \\
Grass Land & 155,280 & 30 \\
Forest Land & 305,384 & 59 \\
Urban Land & 15,528 & 3 \\
Other Land & 15,528 & 3 \\
Total & 517,600 & 100 \\
\hline
\end{tabular}

"Other Land includes Swamps, Wetland, Water, Barren, Farmsteads, and Rural Roads.

The Tangipahoa River is a popular recreational resource for Mississippi and Louisiana states. In Mississippi, the Tangipahoa River is classified as fish and wildlife habitat, which is protective of contact recreation during the summer months. There are concerns due to the high pollution loads recorded at that period. In Louisiana, the river is listed as a wild and scenic stream by the Louisiana Scenic Streams Program and is used for recreational contact. Both States have designated the Tangipahoa River as a targeted watershed in their 


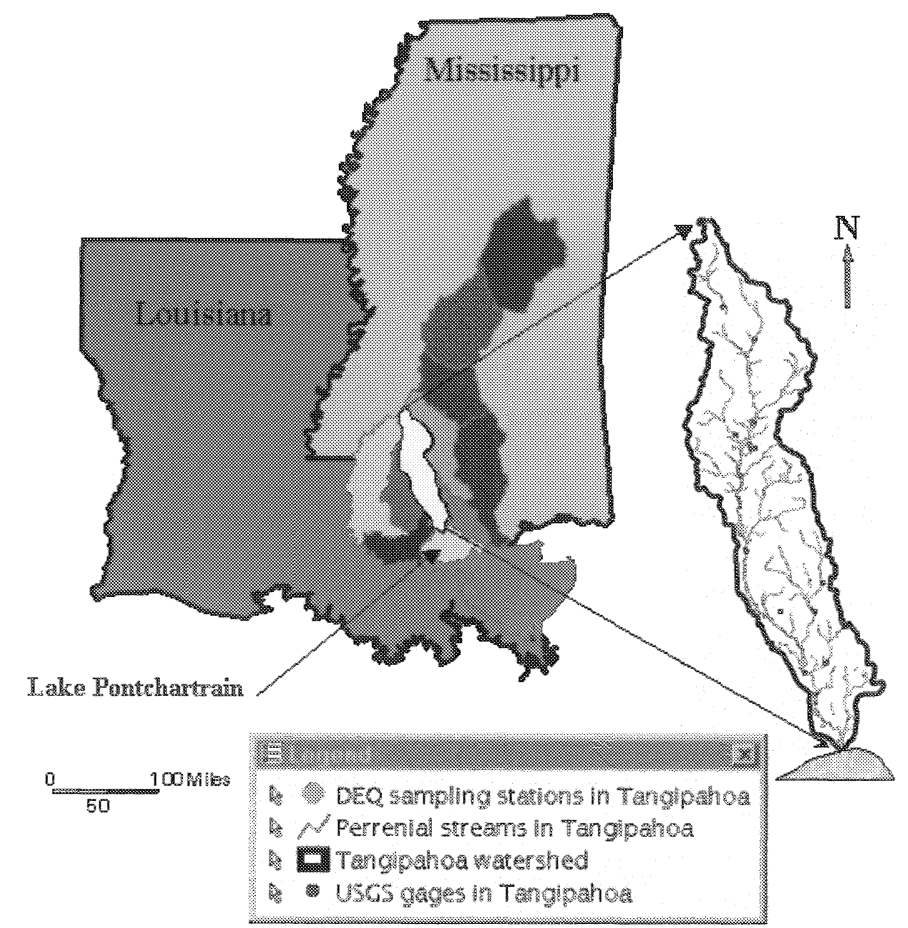

Figure 5.2 Lake Pontchartrain basin and the Tangipahoa watershed.

non-point source management program reports. By this designation, the river has been identified as being potentially impaired by agricultural non-point pollution sources. Surface runoff from the study area and others in the ecosystem represent a major. component in the water balance of Lake Pontchartrain. Therefore, pollutant loads discharged into the lake, accounting for the different land-use activities, have to be estimated (Khairy, 2000). The initial conditions for the SWAT model were established for the year 1979, then the period of 1980-1989 was used in the calibration. Finally, the period 19901995 was used to validate the model.

\subsection{Input Data Development for SWAT}

\section{Study Area Delineation}

The SWAT-GRASS tool, which utilizes existing USGS and Soil Conservation Service (SCS) geographic information resources, is used in this study. The interface used the geographic digital terrain and soil type map layers of 1:100,000 scale and $5 \mathrm{~km} \times 5 \mathrm{~km}$ resolution. The Tangipahoa watershed was 
delineated based on the land-use, soil type and topography into 76 subbasins or hydrologic response units (HRU) about 2,500 ha each, based on the approach of dominant land-use (land-use of less than $20 \%$ of the area was disregarded) and dominant soil type (soil type of less than $10 \%$ of the area was disregarded). Finally, one dominant land-use and one dominant soil type were assigned for each HRU as shown in Figure 5.3 (Khairy, 2000). The SWAT data requirement includes, for example, soils characteristics, topography, geometry and stream flow configuration, hydrologic parameters, land-use, and weather data. The interface develops, aggregates and extracts the data sets, then writes them into the appropriate model input data files. The schematized land-uses used by SWAT are shown in Figure 5.4. The relational SWAT databases include crop development, fertilizers, pesticides, and tillage data sets.

\section{Precipitation and Temperature Data}

Precipitation data records for Tangipahoa watershed were determined using the USGS daily rainfall database. For the daily maximum/minimum air temperature, solar radiation, wind speed, and relative humidity data, the SWAT weather generator technique (Richardson and Wright, 1984) was used.

\section{Dairy Farm and Urban Waste Data}

The animal waste loads in Tangipahoa watershed are relatively large in comparison to domestic waste loads (US-DOA, 1991). The dairy farm and urban waste data were collected from different district offices in Louisiana and Mississippi States (Khairy, 2000).

\section{Stream Flow and Water Quality Data}

The USGS stream flow data (period 1960-1995) and the in-stream water quality data from LDEQ (period 1980-1996) were used for calibration and verification purposes.

\subsection{Results and Discussion}

The hydrologic, sediment, and nutrients calibration were conducted for the Tangipahoa watershed during the period 1980 through 1989. The curve number, available moisture capacity, and the shallow groundwater evaporation factor were the major calibration parameters for hydrology. Soil erosion factor and soil cover/biomass factor were used for the sediment calibration. The rainwater nutrient $(\mathrm{N}$ and $\mathrm{P})$ concentrations and the initial soil $(\mathrm{N}$ and $\mathrm{P})$ contents were the dominant parameters for nutrient loads calibration. 


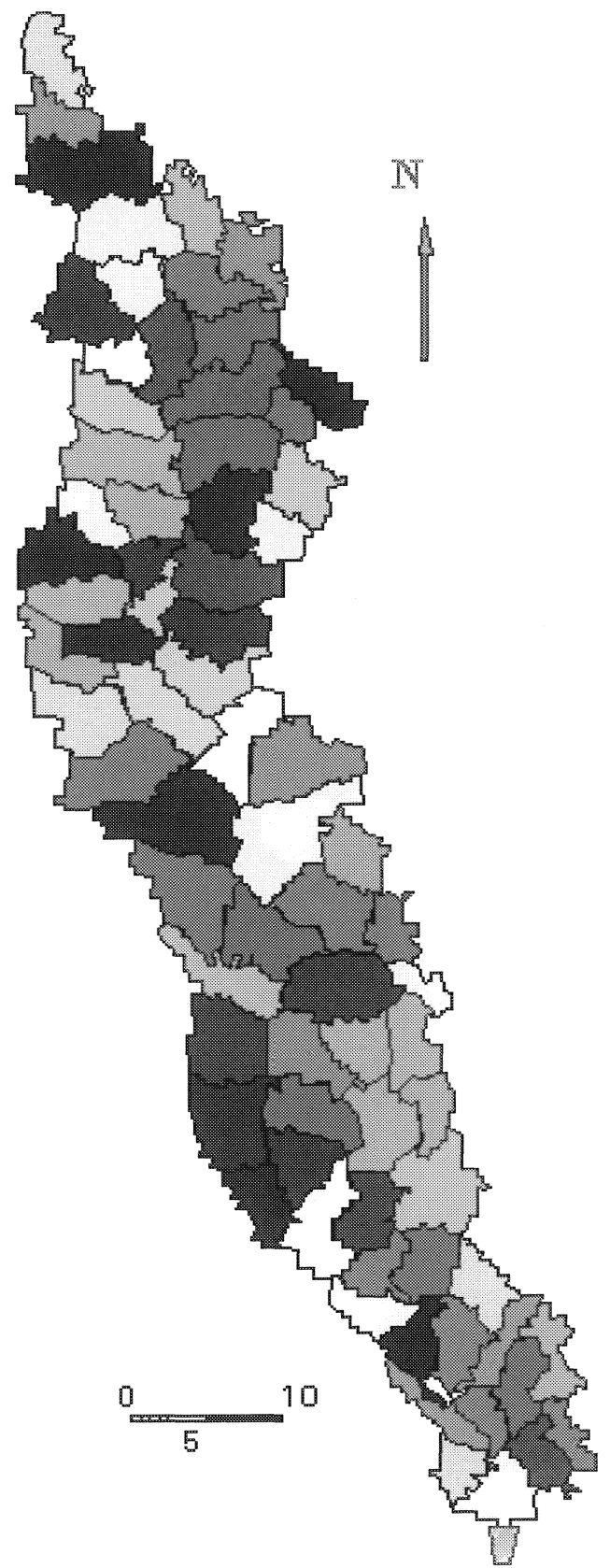

Figure 5.3 Tangipahoa watershed delineation by SWAT (76 sub-basins). 


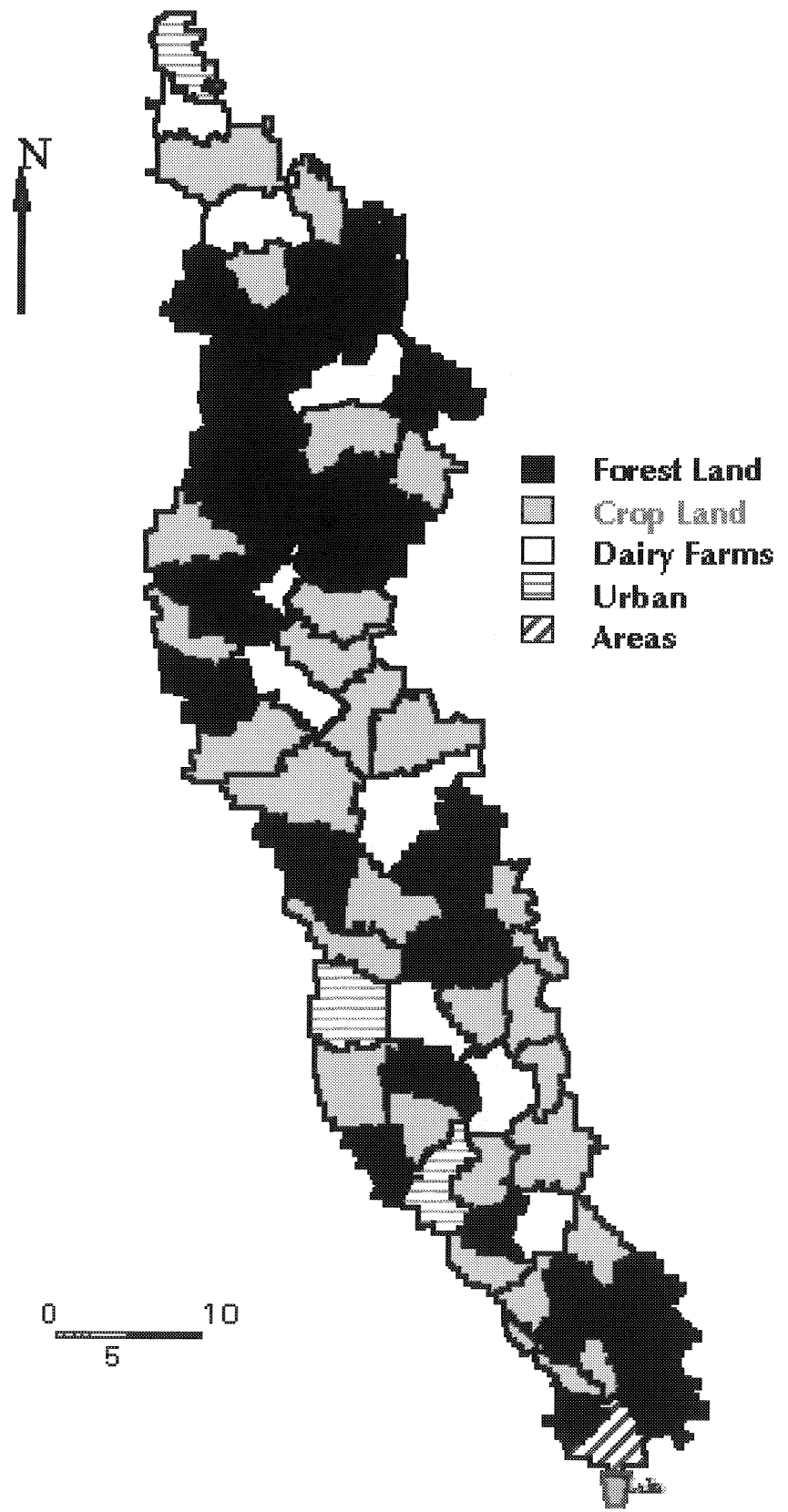

Figure 5.4 Various land-use activities in the Tangipahoa watershed . 
Comparisons between measured and computed stream flow at Tangipahoa watershed outfall at Robert location on annual and monthly basis are shown in Figures 5.5 and 5.6. Computed and measured values are in good agreement. SWAT over-estimates the storm peak flow unless it is calibrated with high consideration to the interactive effects of a group of hydrologic input parameters in the same time using the objective function approach (Arnold and Allen, 1996). Figure 5.7 shows the scatter plot of observed and predicted monthly flow at Robert location in 1980 (typical year). The coefficient of determination $\left(\mathrm{R}^{2}\right)$ for the linear regression between the monthly observed and simulated stream flow is 0.977 . The slope of the regression line is 1.306 and is marginally different from 1.0 at $95 \%$ confidence level. The average Nash-Suttcliffe coefficient during the calibration period was 0.867 (Khairy, 2000). Therefore, the model performance, considering average flow rates over the entire simulation period, is considered successful, and the SWAT model computed the stream flow at the Tangipahoa watershed outlet location satisfactorily.

The modified recursive digital filter technique by Arnold and Allen (1999) was used for Tangipahoa watershed baseflow calibration during the period of 1984-1995, due to the unavailability of baseflow measurements. A comparison between the automated filter baseflow and the SWAT baseflow estimates at the watershed outlet (Robert location) on a daily basis is shown in Figure 5.8. Results compare well except at the storm peak for single events. The digital filter over-estimates baseflow values. Both digital filter and SWAT model methods for estimation of baseflow to streams have inherent errors, uncertainties, and in some cases the water balance model may give more reliable estimates than the recession method (Arnold and Allen, 1999).

The computed average annual sediment load to Lake Pontchartrain was $0.195 \mathrm{t} /$ (ha.y) whereas the measured sediment was about $0.20 \mathrm{t} /$ (ha.y), Figure 5.9. The correlation coefficient between the measured and estimated annual average sediment loads was 0.65 , Figure 5.10. Generally, the long-term estimated average annual sediment transport was close to the average value measured by LADEQ.

The SWAT estimates for the nitrate-N and soluble-P loads against the measurements at Robert location are shown in Figures 5.11 and 5.12. The measured and estimated yearly loads of both nitrate- $\mathrm{N}$ and soluble-P are in very good agreement except for years 1980 and 1983. Those two years had high intensity and volume of rainfall. The SWAT model relates nitrate-N and soluble$\mathrm{P}$ loads in rainwater to the volume of rain, therefore some estimated load peaks show up during those years. Another explanation for that unexpected disagreement for the aforementioned years could be the inaccuracy of the EPA grab samples, which may not have been representative of an annual average suite of 


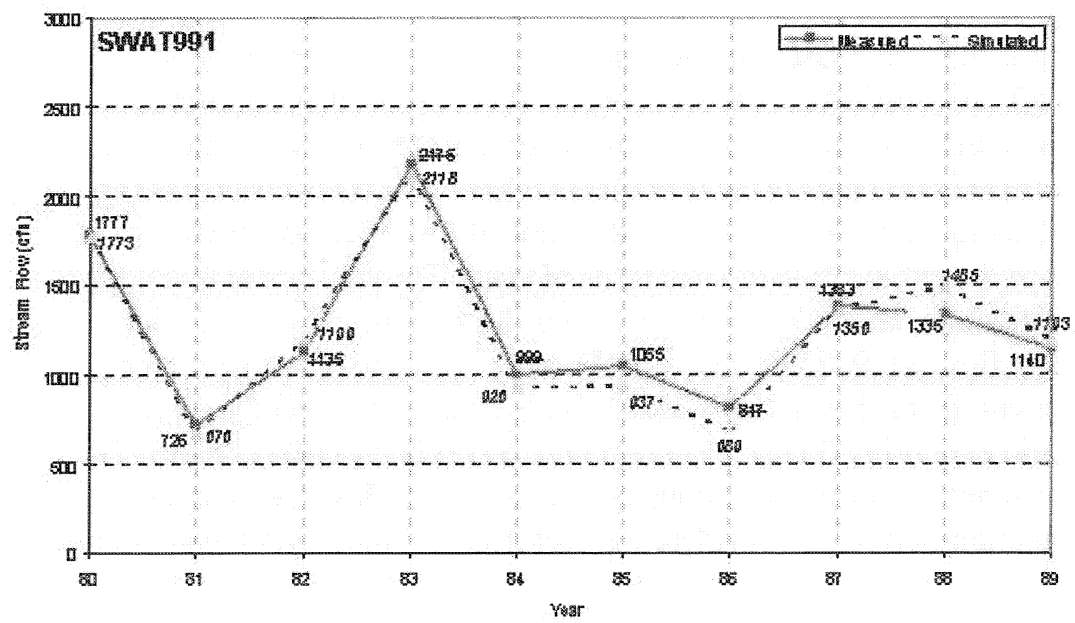

Figure 5.5 Measured vs simulated average annual stream flow at Tangipahoa watershed outflow location (at Robert) during the period 1980-1989.

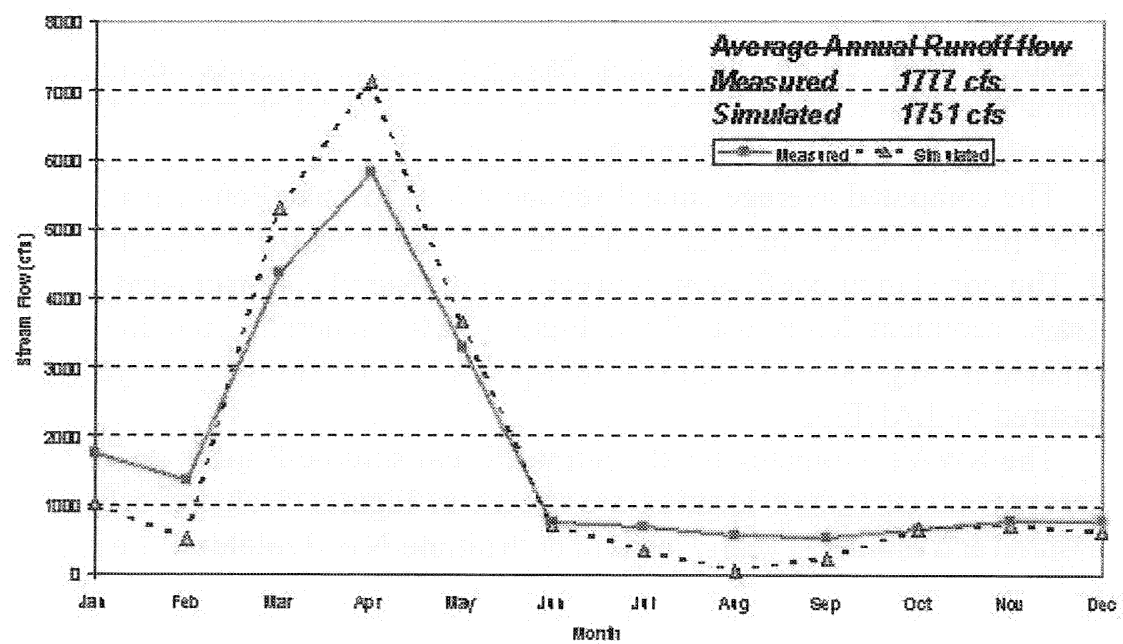

Figure 5.6 Measured vs simulated monthly average stream flow at Tangipahoa watershed outflow location (at Robert), year 1980. 


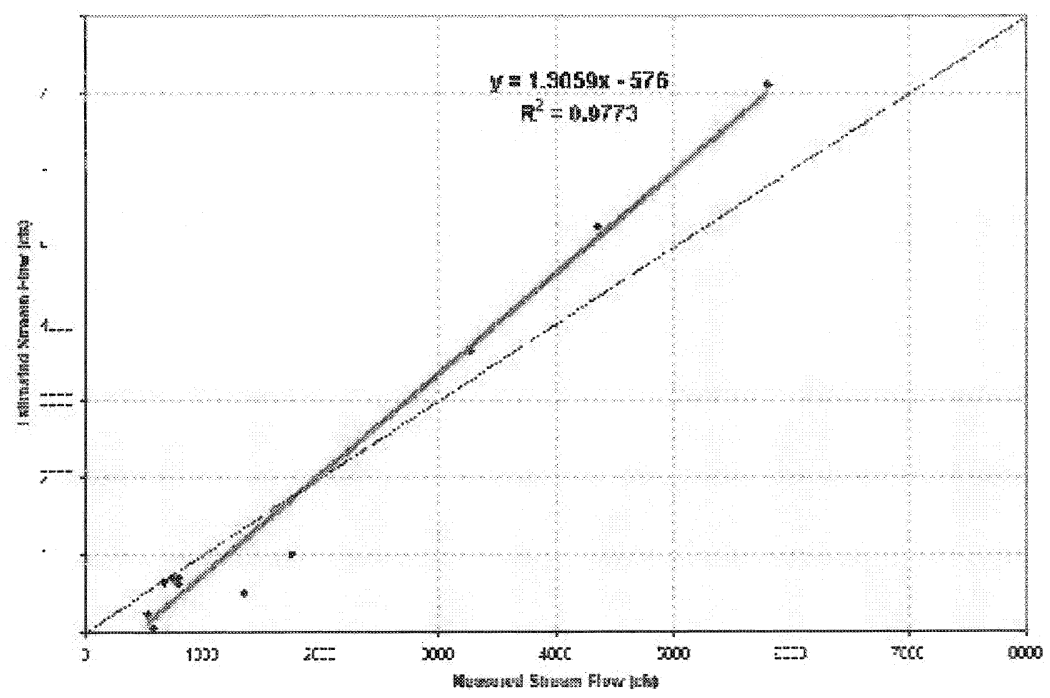

Figure 5.7 Scatter plot of observed against predicted monthly flow at Robert location for year 1980 .

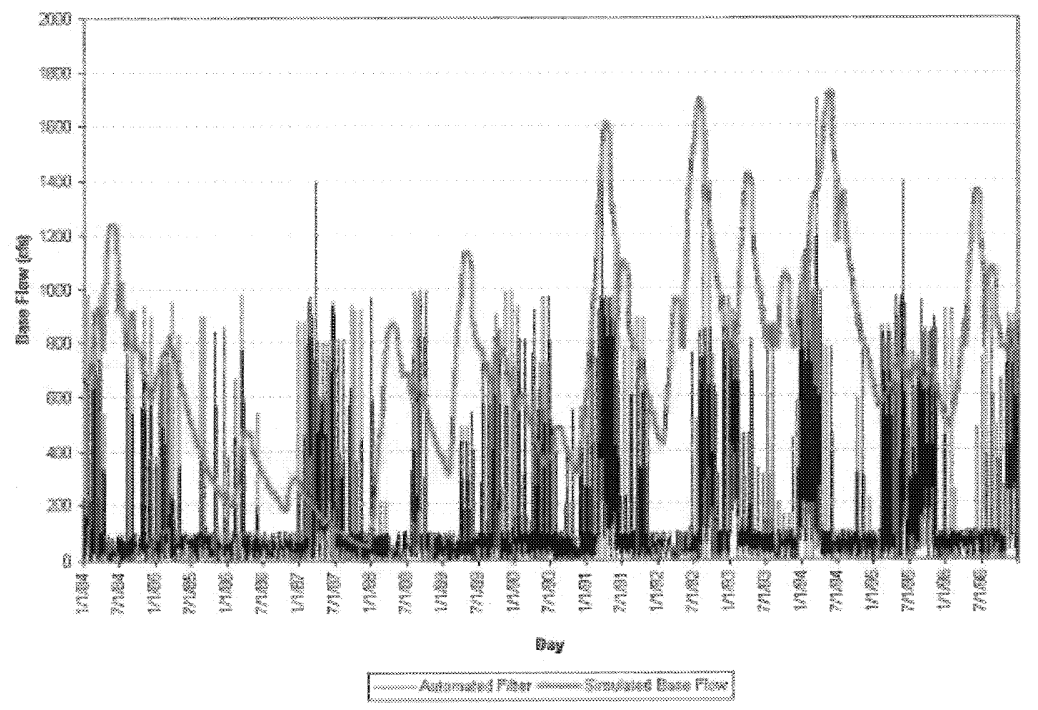

Figure 5.8 Digital automated base flow against SWAT simulated base flow on daily basis (estimated at Robert location). 


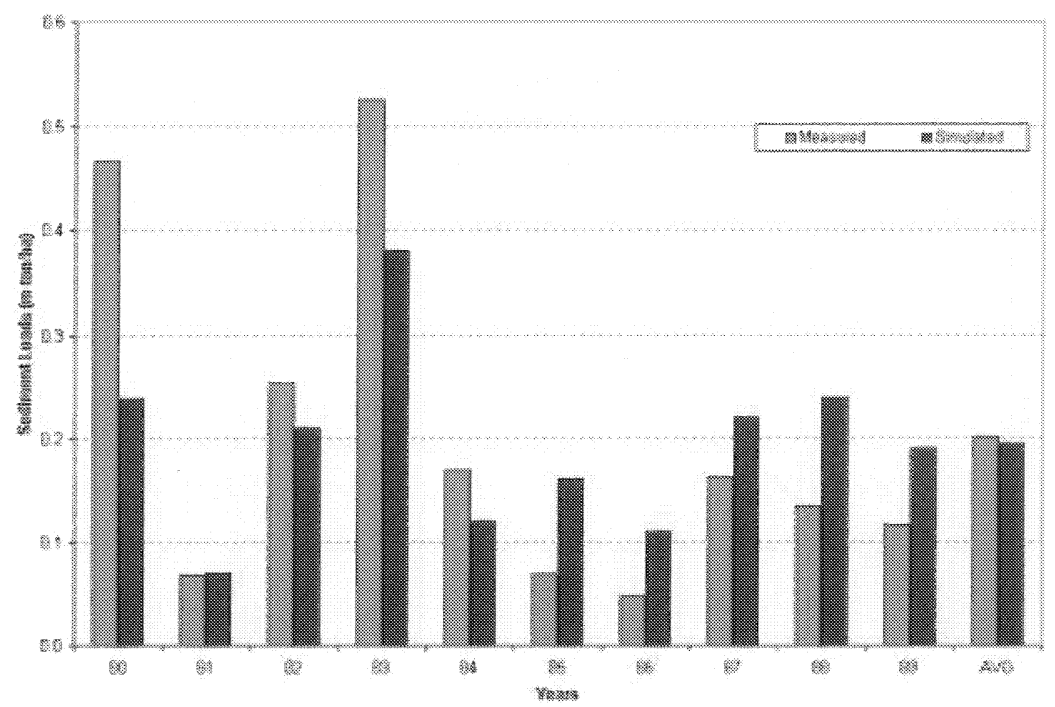

Figure 5.9 Average annual measured against simulated sediment loads at Tangipahoa watershed outlet (at Robert location).

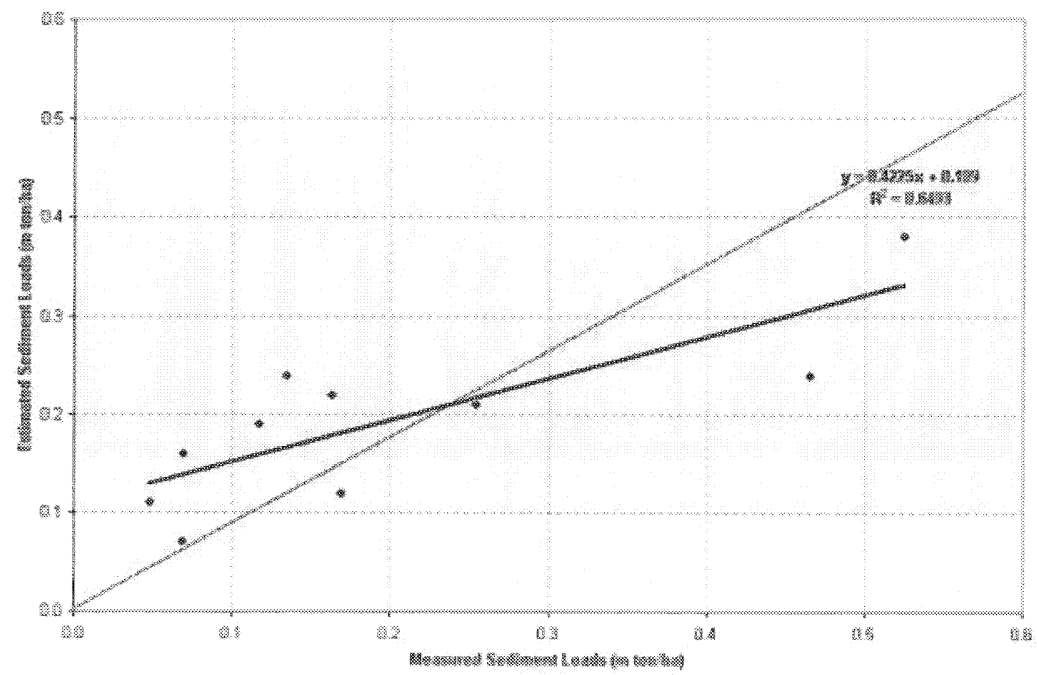

Figure 5.10 Scatter plot of average annual measured against estimated sediment loads at Tangipahoa watershed outlet at Robert location (1980-1989) 


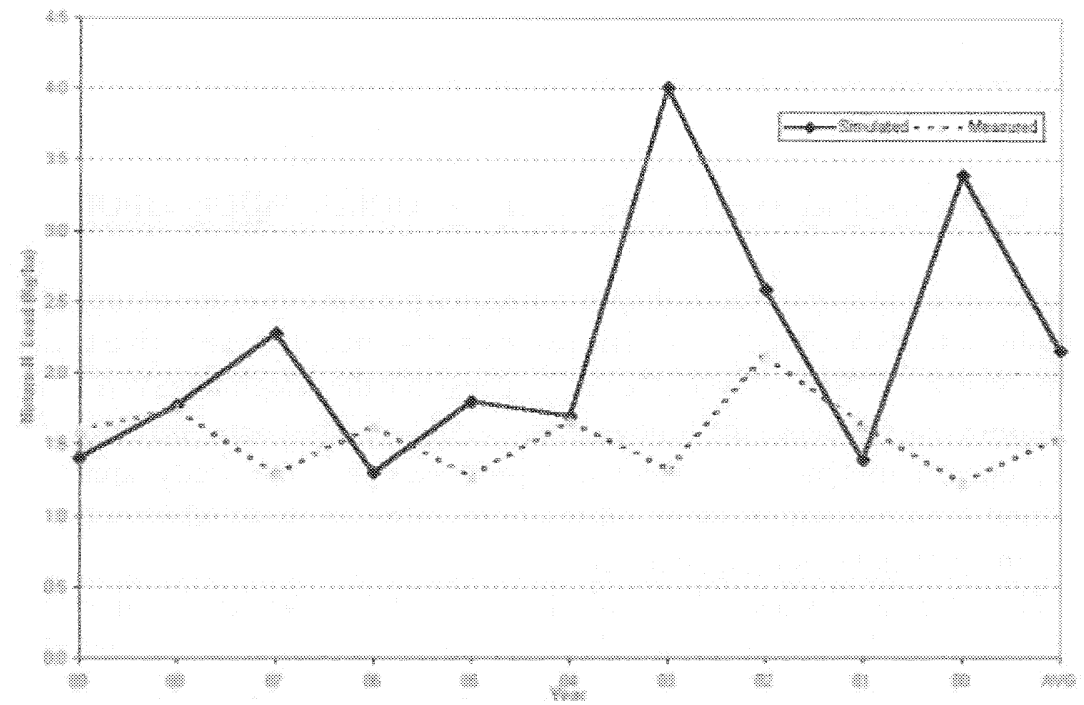

Figure 5.11 Calibration of nitrate-N loads estimates by SWAT at Tangipahoa watershed outlet during the period 1980-1989.

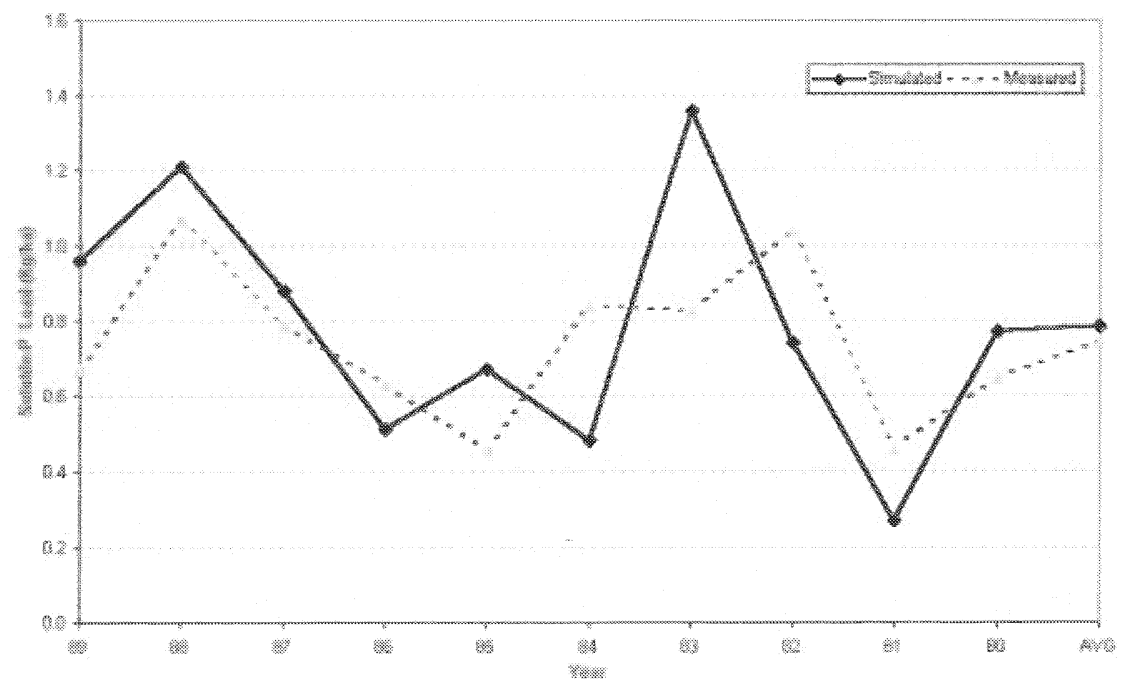

Figure 5.12 Calibration of the soluble-P loads estimates by SWAT at Tangipahoa watershed outlet during the period 1980-1989. 
storms and loadings. Because the SWAT modeling procedure attempted to quantify the yearly average hydrology of the watershed, comparisons with any single measurement can provide only rough verification.

\subsection{Concluding Remarks and Potential Applications}

The accounting of spatial variability of watershed parameters is one of the major strengths of the SWAT-GIS tool. The results of the model are sensitive to data resolution in the GIS map layers. Results suggest that the integrated SWAT-GIS tool significantly reduces the time required to obtain input data and simplifies model operation. Once the watershed processes and the study areas are identified, land-use management and practices can be investigated for optimum environmental and modeling objectives.

The water quality part of the SWAT model is still under development. The relative changes that are shown should be regarded as qualitative, but numerical values are presented to show the trends of the computation and the ultimate potential of this type of model for evaluating management scenarios.

In general, the annual and monthly stream flow rates and nutrients loadings computed by SWAT correspond very well with the observed values. Nevertheless, the model overestimates the daily totals particularly during the spring/ summer months. Watershed management options proposed to improve water management and environmental aspects can be assessed for effectiveness using the SWAT tool.

\section{Acknowledgments}

The authors wish to thank The Drainage Research Institute, National Water Research Center, Egypt, Freeport Mc MoRan Inc, and The University of New Orleans, USA, for financial support of this project. The technical assistance of Dr. Jeff Arnold, Blackland Research Center, Texas Agriculture Experimental Station, Temple, Texas, and Dr. George Sabbagh, University of Texas A \& M, College Station, Texas, are highly appreciated.

\section{References}

Arnold, J.G. and P.M. Allen, 1999. Validation of automated methods for estimating base flow and groundwater recharge from stream flow records. J. American Water Resources Assoc. 35(2): 411-424. 
Arnold, J.G., and P.M. Allen, 1996. Simulating hydrologic budgets for three Illinois watersheds. J. of Hydrology 176 (1996):57-77.

Arnold J.G., R. Srinivasan, 1999. Simulating of In-stream Water Quality, ongoing research. Blackland Research Center, Texas Agricultural Experimental Station, Temple, TX.

Arnold J.G., P.M. Allen, and G. Bernhardt, 1993. A comprehensive Surface-Groundwater Flow, Model. J. Hydrology 142:47-69.

Goran W. D., 1983. An Interactive Soils Information System Users Manual. U.S. Army Construction Engineering Research Laboratory Technical Report, No163.

Khairy W.M., 2000. Integrated Watershed Management for Optimum Environmental Quality of Aquatic Systems, Ph.D. Dissertation, Dept. of Civil \& Environmental Engineering, University of New Orleans, Louisiana, USA (expected May 2000).

Neitsch S.L., J.G. Arnold, and J.R. Williams, 1999. Soil Assessment Tool User's Manual, ver. 98.1, Blackland Research Center, Texas Agricultural Experimental Station, www.brc.tamus.edu/swat/ and www.brc.tamus.edu/swat/swatgrass/

Rewerts C.C. and B.A. Engel, 1991. ANSWERS on GRASS: Integrating a Watershed simulation with a GIS. ASAE Paper No. 91-2621, American Society of Agr. Eng., Michigan.

Richardson C.W., and D.A. Wright. 1984. WGEN: A model for generating daily weather variables. USDA Agricultural Research Service, ARS-8.

Srinivasan R., and B.A. Engel, 1991a. A Knowledge Based Approach to Extract Input Data from GIS. ASAE Paper No. 91-7045, American Society of Agr. Eng., Michigan.

Srinivasan R., and B. A. Engel, 1991b. GIS: A Tool for Visualization and Analyzation. ASAE Paper No. 91-7574. American Society of Agricultural Engineers, St. Joseph, Michigan.

Srinivasan R., J. Arnold, R. S. Muttiah, C. Walker, and P. T. Dyke, 1993. Hydrologic Unit Model for United States (HUMUS). In: Proc. Advances in Hydro-Science and-Engineering. CCHE, School of Engineering, The University of Mississippi, MS.

U.S. Department of Agriculture, Soil Conservation Service, and Forest Service, 1991. Tangipahoa River Cooperative Basin Study, Amite, Lincoln, and Pike counties, MS.

U.S. Army, 1988. GRASS Reference Manual. USA CERL, Champaign, Illinois, http:/ /www.baylor.edu/ grass/

USDA-SCS, 1992. STATSGO - State Soils Geographic Data Base. Soil Conservation Service, Publication Number 1492, Washington, D.C.

Williams J.R., A.D. Nicks, and J.G. Arnold. 1985. Simulator for water resources in rural basins. Journal of Hydraulic Engineering 111(6): 970-986. 
